\title{
Erratum to: Transcutaneous electrical posterior tibial nerve stimulation for faecal incontinence: effects on symptoms and quality of life
}

Veronique Vitton • Henri Damon • Sabine Roman •

François Mion

Published online: 3 August 2010

(C) Springer-Verlag 2010

Erratum to: Int J Colorectal Dis

DOI 10.1007/s00384-010-0962-1

The original version of this article unfortunately contained a mistake. The authors' names are incorrectly presented. They correct presentation is: Veronique Vitton, Henri Damon, Sabine Roman and François Mion.

The online version of the original article can be found at http://dx.doi. org/10.1007/s00384-010-0962-1.

V. Vitton $\cdot$ H. Damon $\cdot$ S. Roman $\cdot$ F. Mion

Hospices Civils de Lyon, Physiologie digestive,

Hôpital Edouard Herriot,

Lyon, France

S. Roman - F. Mion

Université Lyon 1,

Lyon, France

V. Vitton $(\bowtie)$

Hôpital NORD,

Marseille, France

e-mail: vittonv@yahoo.com 